DOI https://doi.org/10.30525/978-9934-26-038-4-5

\title{
CHARACTERISTICS OF BLOOD LIPIDS PECTRUM IN PATIENTS WITH ACUTE CORONARY SYNDROME (ACS) ON THE BACKGROUND OF PROLONGED QT INTERVAL
}

\author{
Bilous Z. O. \\ Assistant at the Department of Internal Medicine № 1 \\ Danylo Halytsky Lviv National Medical University \\ Lviv, Ukraine
}

Topicality. Cholesterol is the main building block of our body. However, changes in its quantitative and qualitative composition contribute to the emergence and increase in the risk of cardiovascular complications. Thus, in $95-97 \%$ of cases the cause of coronary heart disease (CHD) is atherosclerosis, which is based on a violation of the lipid spectrum of the blood with the formation of an atherosclerotic plaque that may become a weak link due to instability of its coverover time [1, p. 691; 5, p. 312]. Such patients will clinically have signs of acute coronary syndrome (ACS) [3, p. 37; 4, p. 588]. Acute myocardial ischemia can lead to the prolong ation of QT interval which will be an unfavorable prognostic sign for this group of patients [2, p. 50].

Purpose: to characterize the state of blood lipid spectrum in patients with acute coronary syndrome on the background of prolonged QT interval.

Materials and methods. 43 medical histories were analyzedretrospectively. Patients were divided into two groups: 1 group -22 patients with ACS and prolonged QT interval, 2 (control) group - 21 patients with ACS with normal QT interval values. ACS wasdiagnosed according to the recommendations of the European Society of Cardiologists and protocols for the provision of medical care to cardiac patients (Unified clinical protocol for emergency, primary, secondary (specialized), tertiary (highly specialized) medical care and medical rehabilitation of acute coronary syndrome without elevation of ST segment (order No. 164 of the Ministry of Health of Ukraine dated March03, 2016); unified clinical protocol of emergency, primary, secondary (specialized) and tertiary (highly specialized) medical care and medical rehabilitation of acute coronary syndrome with elevation of ST segment (order No. 455 of the Ministry of Health of Ukraine dated July 03, 2014). Groups of patients were comparable in age and sex and did not use statins and any other medication to correct the lipid spectrum of the blood before taking part in the study. All patients underwent Holter ECG monitoring and blood lipid spectrum parameters were determined: total cholesterol 
(Tcholesterol), high-density lipoprotein cholesterol (HDL cholesterol), lowdensity lipoprotein cholesterol (LDL cholesterol), very low-density lipoprotein cholesterol (VLDL cholesterol), triglycerides (TG).

Results and discussion. In group 1 the average values of total cholesterol were $6.80 \pm 1.27 \mathrm{mmol} / \mathrm{l}$, in group $2-6.60 \pm 1.81 \mathrm{mmol} /$ lrespectively. High-density lipoprotein cholesterol (HDL cholesterol) was slightly higher in patients of group 2, but these changes did not turn out to be reliable(p> 0.05 ): in group $1-1.1 \pm 0.37 \mathrm{mmol} / 1$, in group $2-1.2 \pm 0.33 \mathrm{mmol} / 1$. HDL cholesterolwas slightly but significantly $(\mathrm{p}<0.05)$ higher in patients with ACS and prolonged QT interval: in group $1-3.3 \pm 0.70 \mathrm{mmol} / 1$, in group $2-1.2 \pm 0.55 \mathrm{mmol} / 1$. The same changes were characteristic of very low-density lipoprotein cholesterol ( $\mathrm{p}<0.05)$. TG was higher in patients with normal QT duration: group $1-3.02 \pm 0.27$, group $2-3.11 \pm 0.31 \mathrm{mmol} / 1$ $(\mathrm{p}<0.05)$.

In patients with ACS and prolonged QT there is a direct, moderate correlation $(\mathrm{r}=0.52, \mathrm{p}<0.05)$ between the duration of QT interval and total cholesterol. A similar correlation $(r=0.58, \mathrm{p}>0.05)$ is characteristic of LDL cholesterol in this group. For other fractions of cholesterol, a slight correlation was found ( $p>0.05$ ).

Conclusions. Significant changes in proatherogenic cholesterol fractions have been found in patients with ACS andprolonged QT; the presence of positive correlations between the duration of QT segment in patients with ACS and blood lipid spectrum primarily due to total cholesterol and lowdensity lipoprotein cholesterolhave beenestablished.

\section{References:}

1. Chalmers J, Pullan M, Fabri B, McShane J, Shaw M, Mediratta N [et al.] Validation of EuroSCORE II in a modern cohort of patients undergoing cardiac surgery. Eur JCardiothorac Surg 2013;43(4):688-694.

2. Gussak I., Brugada P., Brugada J. et al. ECG phenomen of idiopathic and paradoxical short QT intervals. Cardiac Electrophysiol Rev. - 2002. Vol. 6. P. 49-53.

3. Steg PG, James SK, Atar D, Badano LP, Blömstrom-Lundqvist C, Borger MA, [et al.] ESC Guidelines for the management of acute myocardial infarction in patients presenting with ST-segment elevation. The Task Force on the manage-ment of ST-segment elevation acute myocardial infarction of the European Society of Cardiology (ESC) European Heart Journal 2012; 33:26-69.

4. The effects of lowering LDL cholesterolwith statin therapy in people at lowrisk of vascular disease: meta-analysis of individual data from 27 randomised trials / B. Mihaylova, J. Emberson, L. Blackwell // Lancet. 2012. - Vol. 380. - P. 581-590. 
5. The ORIGIN Trial Investigators. N-3 fatty acids and cardiovascular outcomes in patients with dysglycemia / H.C. Gerstein, J. Bosch, G.R. Dagenais // N. Engl. J. Med. - 2012. - Vol. 367. - P. 309-318.

DOI https://doi.org/10.30525/978-9934-26-038-4-6

\title{
РЕССТРАЦІЯ ПРОСТОРОВОГО ПЕРЕМІЩЕННЯ НИЖНЬОЇ ЩЕЛЕПИ ПРИ ОБСТЕЖЕННІ ХВОРИХ З М'ЯЗОВО-СУГЛОБОВОЇ ДИСФУНКЦІЮ СКРОНЕВО-НИЖНЬОЩЕЛЕПНОГО СУГЛОБА
}

\author{
Боян А. М. \\ кандидат медичних наук, \\ дочент кафедри ортопедичної стоматології \\ Харківська медична академія післядипломної освіти
}

Куцевляк В. I.

доктор медичних наук,

професор кафедри стоматології дитячого віку,

ортодонтії та імплантології

Харківська медична академія післядипломної освіти

м. Харків, Україна

В основі м'язово-суглобової дисфункції (МСД) скронево-нижньощелепного суглоба (СНЩС) лежить порушення координованої функції жувальних м'язів, скронево-нижньощелепного суглоба і взаємного розташування елементів СНЩС, а саме головки та диска щодо горбка [1-3]

Поширеність даного захворювання зустрічається від 40-82\% від кількості хворих, які звернулися за стоматологічною допомогою [4; 5].

В останні роки з'явилися дані про поширеність патології СНЩС у осіб вікової категорії від 18 до 22 років [6].

Діагностика МСД СНЩС розглядається як, безсумнівно, важливий, але при цьому досить складний етап. Саме проведення діагностичних методів для визначення патології щелепно-лицевої ділянки, дозволяє визначити необхідні заходи для якісного стоматологічного лікування [7; 8].

Відомо, що при МСД СНЩС, жувальні м'язи певної групи, як правило, функціонально перевантажені, в м'язах виникають тригерні зони, вони працюють в патологічному режимі. Причинами всього цього можуть бути дефекти зубного ряду, патологічна стертість зубів, патологія 